\title{
Parasitological Prevalence of Bovine Trypanosomosis in Kubo Division of Kwale County of Coastal: Baseline Survey
}

\author{
Mbahin, N., H. Affognon, J. Andoke, \\ M. Tiberius, D. Mbuvi, J. Otieno, P. Muasa and R.K. Saini \\ Animal Health Division, African Insect Science for Food and Health, \\ International Centre of Insect Physiology and Ecology, P.O. Box: 30772-00100, Nairobi, Kenya
}

Received 2012-06-11, Revised 2012-06-19; Accepted 2013-04-06

\begin{abstract}
Prior to field trials of large scale tsetse repellent technology validation in July 2011, a cross-sectional survey of bovine trypanosomosis and its vectors was carried out to know the disease level in Kwale County of Coastal Kenya. A total of 584 adult cattle were examined at ten different Locations. The trypanosome prevalence in cattle with regard to age, sex, location and apparent tsetse density was investigated. The overall trypanosome prevalence in cattle in Kubo Division of Kwale County was 33.9\%. Two types of infections were recorded in various parts of the Division in the following proportions: T. congolense $61.1 \%$, T. vivax $38.9 \%$. Findings from this study indicated that the Location dependent trypanosome prevalence can be stratified in three main levels: high (Mkongani 16.7\%); very high in (Kizibe 25\%, Zunguluka 25.5\% and Mangawani 26.7\%) and extremely high in (Katangini 32.2\%, Mkanda 34.4\%, Msulwa 42.4\%, Mawia 46.4\% and Kidongo 52.5\%). The mean apparent density for $G$. pallidipes was 30 flies/trap/day while that of $G$. austeni 0.8 flies/trap/day and $G$. brevipalpis was 0.4 flies/trap/day. There was a positive and significant correlation $(\mathrm{p}<0.05, \mathrm{r}=0.82)$ between the trypanosome prevalence and tsetse apparent density. In view of the risk of trypanosomosis, the Division was selected for the large scale field trials of the new tsetse repellent technology validation.
\end{abstract}

Keywords: Trypanosomosis, Prevalence, Tsetse Repellent Technology, Kubo Division Kwale District

\section{INTRODUCTION}

Trypanosomiasis is one of the main constraints to sustainable livestock production in sub-Saharan Africa (Swallow, 1999) where about 50-70 million animals are at risk (Geerts et al., 2001). Tsetse flies (Glossina sp.), the principal vector of trypanosomes, inhabit about 10 million $\mathrm{km}^{2}$ of the continent. Livestock trypanosomosis has adverse effects on rural development over vast areas (Holmes, 1997). Tsetse-transmitted trypanosomosis in human and domestic animals poses also a serious threat to the lives and livelihoods of entire communities and constitutes the greatest single constraint to livestock and crop production and to a more appropriate and responsible utilization of natural resources in Africa. The direct and indirect impacts of African Animal Trypanosomosis on agriculture constitute a major constraint to the socio-economic development of tsetse fly (Glossina) infested areas of Africa (Swallow, 1999). Estimation of the annual economic impact by the Food and Agriculture Organization of the United Nations (FAO) establish that, every year, Africa loses over 3 million cattle and other domestic livestock through deaths caused by trypanosomosis. Approximately 35 million doses of trypanocidal drugs (worth about US \$35 million) is bought every year in futile efforts to maintain livestock free of the disease. The annual loss directly attributed to trypanosomosis, in terms of reduced meat

Corresponding Author: Mbahin, N., Animal Health Division, African Insect Science for Food and Health, International Centre of Insect Physiology and Ecology, P.O. Box: 30772-00100, Nairobi, Kenya 
and milk production and in terms of the costs related to treating the disease or controlling the vector, has recently been estimated at US $\$ 1.2$ billion. This figure rises to over US $\$ 4.5$ billion per year, if losses in potential crop and livestock production attributable to the disease are considered and excludes the losses attributable to the effects of sleeping sickness in humans (PATTEC, 2000).

In endemic areas, trypanosomiasis reduces calving rates, milk yields, off take and oxen work efficiency whereas calf mortality is increased (Swallow, 1999). The disease, transmitted by tsetse flies, is caused by an infection with pathogenic trypanosomes. Such an infection causes an acute or chronic disease characterized by fever, anemia, loss of appetite and condition. Mortality and morbidity vary widely and depend on factors such as the host species and breed, the trypanosome species, the virulence of the parasite and the innate resistance of the host (Connor and Bossche, 2004).

Various options are available for the control of animal trypanosomosis; they include the suppression and/or eradication of tsetse populations (Jordan, 1986), the use of trypanotolerant breeds of livestock (D'Ieteren et al., 1998), chemotherapy (Peregrine, 1994) or combinations of these (Holmes, 1997). But today, the current unfavorable economic environment has prompted a shift in emphasis from large-scale tsetse eradication campaign to small-scale, sustainable and environmentally friendly trypanosomosis control. As a consequence, control focuses on areas where bovine trypanosomosis is a constraint to development and where disease management practices can be improved, knowing that animal traction plays an important role in the intensification of crop production in developing countries.

This present study sought to obtain prevalence estimates of bovine trypanosomosis, transmitted by tsetse flies and the apparent density of tsetse and biting flies around Shimba hills national reserve, prior to field trials of large scale tsetse repellent technology validation in July 2011.

\section{MATERIALS AND METHODS}

\subsection{Study Areas}

This study was carried out in Kubo Division, Kwale County in the Coast Province of Kenya. Kwale County lies between latitudes $3^{\circ} 3^{\prime} \mathrm{S}$ and $4^{\circ} 45^{\prime} \mathrm{S}$ south and longitudes $38^{\circ} 31^{\prime} \mathrm{E}$ and $39^{\circ} 831^{\prime} \mathrm{E}$. Kwale County covers an area of $1,043 \mathrm{~km}^{2}$ which is divided into two administrative divisions, namely Matuga and Kubo divisions: the study area (Fig. 1) is situated in Kubo division. The populations of Kubo and Matuga division based on 2009 census were estimated to be 649,931 and 151,978 persons, respectively (Njenga et al., 2011).

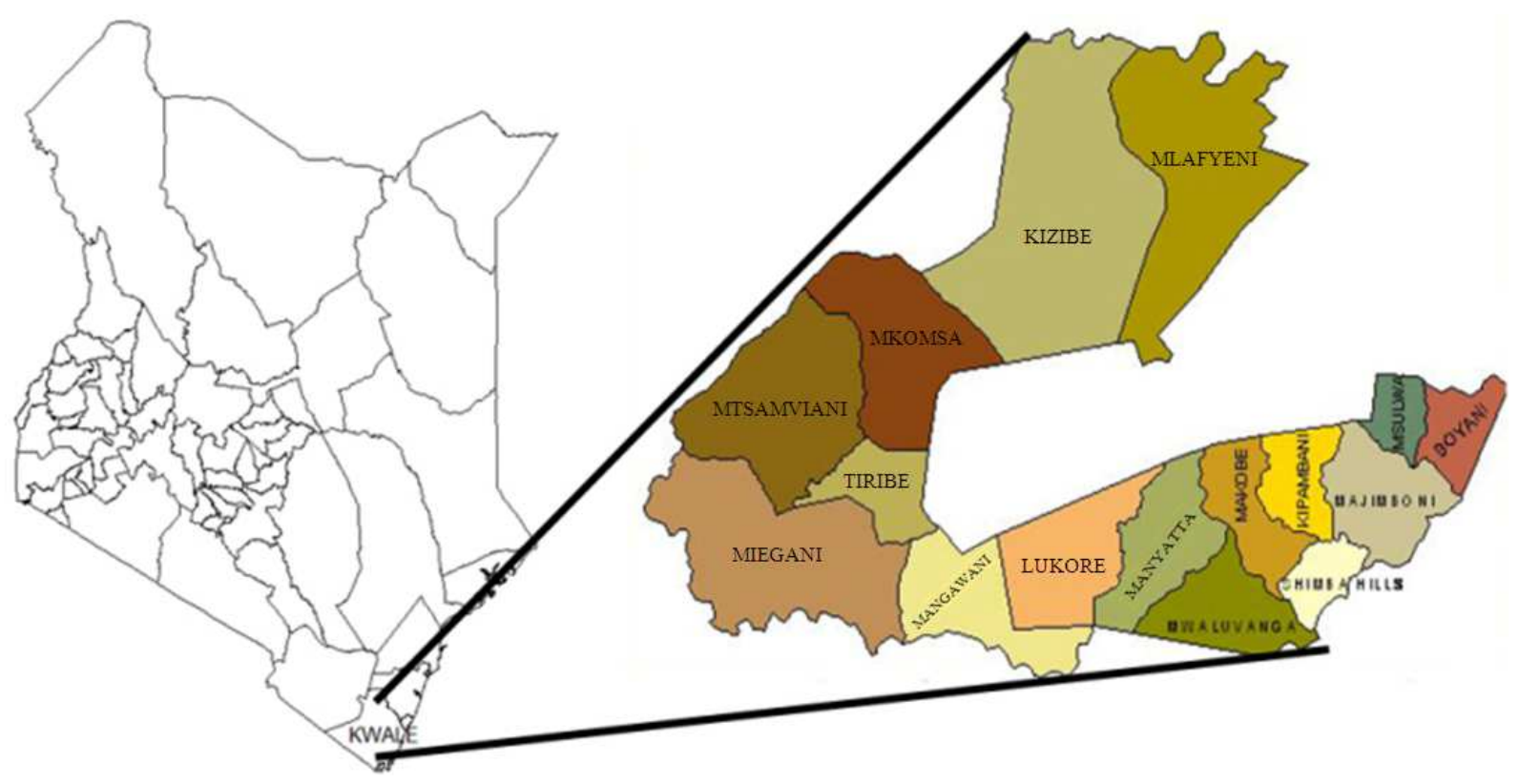

Fig. 1. Study zone: Kwale County in Kenya 
It borders Taita Taveta to the West, Kilifi district to the North West, Mombasa and Indian Ocean to the East and Republic of Tanzania to the South. Kwale County has four major topographical features namely the coastal plain, the foot plateau, the coastal uplands and the nyika plateau. The coastal uplands our study site, commonly known as Shimba Hills rises steeply from the foot plateau to an altitude of 150-462 $\mathrm{m}$ above sea level. They are composed of the mazeras sandstones. The hills include the Shimba Hills (420 m), Tsimba $(350 \mathrm{~m})$ and Dzombo (462 m). This is an area of medium to high agricultural potential (Jaetzold and Schimdt, 1983). In terms of climate, the County is hot and dry from January to March and relatively cool from June to August. Rainfall pattern is bimodal with long rains normally occurring between mid March and June while the short rains occur between October and December. The County has an average rainfall ranging from 400-1200 $\mathrm{mm}$. The mean annual minimum and maximum temperature are 24 and $36^{\circ} \mathrm{C}$, respectively and the County is long rain dependant for its farming activity. Seasonal rivers and the Ramisi River form the drainage pattern in the district. The main rivers and streams are Marere, Mwalunganje and river Ramisi. Due to the fact that Kwale has Shimba Hills National Reserve and on its boundary with Taita Taveta is Tsavo National Park, this area is endowed with variety of wild game like elephants, buffaloes, warthogs, bush pigs, sable antelopes, waterbucks, leopards and monkeys among others. This makes it a good breeding environment for tsetse fly and one of the hotspot areas of human-wildlife conflict brought about mainly by elephants. The most affected areas are those mainly surrounding Shimba Hills National Reserve in Kwale and Samburu-Mackinon areas of Kinango. Though the area is suitable for mixed farming, factors such as high evapo-transpiration rates, unreliability of rainfall, human-wildlife conflicts and tsetse infestation make this difficult (Thorpe et al., 1993). Subsistence farming of food crops including maize, cowpeas and cassava is done mainly for domestic consumption whereas coconuts, oranges, mangoes and cashew nuts are also grown for both domestic consumption and as cash crops. The main livestock kept include cattle, goats, ducks and chickens (Njenga et al., 2011).

\subsection{Survey of Bovine Trypanosomosis}

\subsubsection{Sampling}

Ten locations were randomly selected around Shimba Hills National Reserve. Assuming estimated trypanosomosis prevalence of $50 \%$ and with a desired accuracy of $5 \%$ at the $95 \%$ confidence level, an estimated sample size of 482 cattle was obtained
(Cannon and Roe, 1982). To improve on the reliability of the sample size, more than the required number of animals was taken (584 cattle) in the Division. The number of animals selected in each location was based on proportional weighting. At the village level herds were selected by simple random sampling. The number of cattle sampled from a particular herd in a given village depended on proportional weighting; but a minimum of 4 cattle per herd was fixed. Where a chosen herd did not have the required number of cattle, (as calculated by proportional weighting), a second herd was selected by random sampling and the remaining number of cattle made up for by simple random sampling.

At the end of the exercise around ten or eleven herds were selected between all the cattle keepers by location. The sex, age: Heifer $\leq 1$ year and adult $>1$ year and weight of animals were noted.

\subsection{Parasitological Survey}

Parasitological method was used for diagnosis. Blood was collected from an ear vein into two heparinized micro-haematocrit centrifuge capillary tubes. The capillary tubes were sealed with "Cristaseal" (Hawksley) and centrifuged immediately in a microhaematocrit centrifuge for $5 \mathrm{~min}$ at $9000 \mathrm{rpm}$ after sampling (Murray et al., 1977). After centrifugation, the Packed Cell Volume (PCV) was determined. Animals with a $\mathrm{PCV} \leq 24 \%$ were considered to be anaemic. The Buffy coat and the uppermost layer of red blood cells of the first specimen were extruded onto a microscope slide, covered with a cover-slip and examined for the presence of mobile trypanosomes. Samples were examined with a phasecontrast microscope with a $\mathrm{x} 40$ objective lens.

\subsection{Entomological Survey}

A total of $20 \mathrm{Ngu}$ traps (Vestergaard Frandsen Group) were used to monitor tsetse and biting flies population in the study area. Two traps were deployed by Location. The coordinates of each trap position were recorded with a Global Positioning System (GPS). Traps were checked every day for three days. Records were kept of the number, species and sex of the tsetse captured in each trap. A daily mean Index of Abundance (IA) of tsetse was calculated as the mean number of flies (males and females) captured per trap per day.

\subsection{Statistical Analyses}

A t-test was used for all the means comparisons and the Stata 9.2 software (Corp, 2006) was used. 


\section{RESULTS}

\subsection{Prevalence of Trypanosomiaisis}

Using the Buffy coat technique, the mean prevalence of positive samples in Kubo Division was $33.9 \%(\mathrm{n}=198 / 584)$ for bovine trypanosomosis with Trypanosoma congolense $56.06 \%(\mathrm{n}=111 / 198)$ and $T$. vivax $43.94 \%(\mathrm{n}=87 / 198)$ being the pathogenic trypanosomes identified. A statistical significant difference $(p=0.016<0.05)$ was observed between the two pathogens in the Division. The prevalence of trypanosomosis varied among sampling sites (Table 1). The proportion of $T$. congolense infection was higher in Kidongo, Mkongani, Mkanda and Katanguini, while T. vivax was proportionnaly high in Pengo, Kizibe, Zunguluka, Mangawani and Msulwa (Table 1). The highest prevalence was recorded in Kidongo (52.46\%) and the lowest in Mkongani (16.67\%). In almost all survey areas, except Mawiya, the infection rate of $T$. congolense and $T$. vivax was significantly different $(\mathrm{p}<0.05)$ as shown also in Table 1.

\subsection{Prevalence of Trypanosomiaisis Related to Age}

Across the age spectrum of cattle, prevalence was significantly higher $(\mathrm{P}=0.002<0.05)$ in the younger (age $\leq 1$ an) group $36.53 \%(n=179 / 490)$ than in the older (age $>1$ an) group: $20.21 \%(\mathrm{n}=19 / 94)$. Also for the younger age, significant difference $(\mathrm{P}=$ $0.026<0.05)$ was observed between the pathogenic trypanosomes: $55.87 \% \quad(\mathrm{n}=100 / 179)$ for $T$. congolense and $44.13 \%(\mathrm{n}=79 / 179)$ for T. vivax. But for the old age, no significant difference $(\mathrm{P}=$ $0.33>0.05)$ was observed between $T$. congolense and $57.89 \%(\mathrm{n}=11 / 19)$ and $T$. vivax $42.11 \%(\mathrm{n}=8 / 19)$.

\subsection{Prevalence of Trypanosomiaisis Related to Sex}

More male were infected but no significant difference $(p=0.75>0.05)$ was observed between infected male and female, 34.44\% $(\mathrm{n}=114 / 331)$ and $33.2 \%(n=84 / 253)$, respectively.

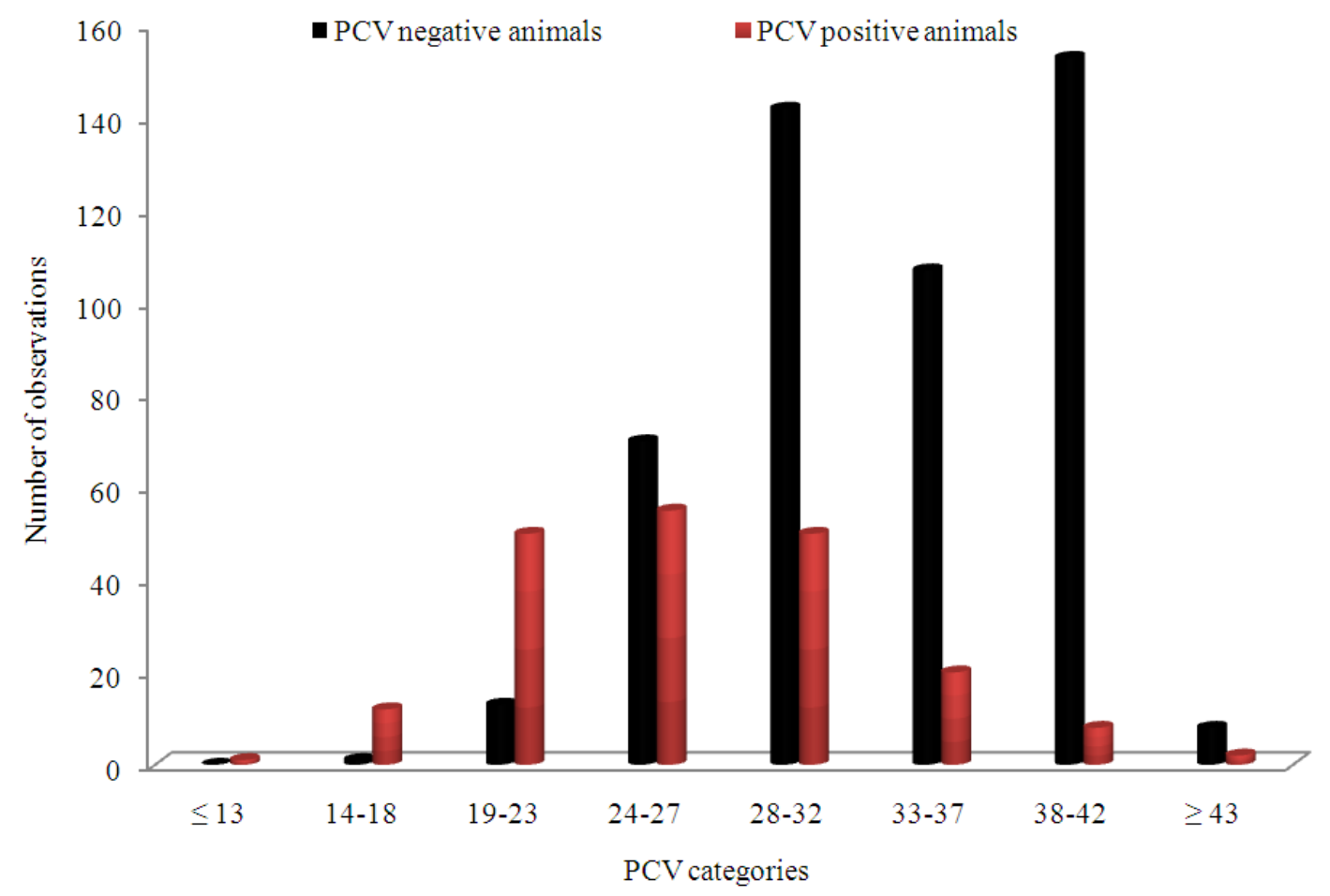

Fig. 2. PCV profile of negative and positive animals in Kwale County 
Mbahin, N. et al. / American Journal of Animal and Veterinary Sciences 8 (1): 28-36, 2013

Table 1. Trypanosomosis prevalence in cattle by Location in Kwale County

\begin{tabular}{|c|c|c|c|c|c|c|c|}
\hline \multirow[b]{2}{*}{ Locations } & \multirow[b]{2}{*}{$\begin{array}{l}\text { Nber of } \\
\text { animals tested }\end{array}$} & \multicolumn{4}{|c|}{ Parasitological result } & \multirow{2}{*}{$\begin{array}{l}\text { Mean PCV } \\
\text { of positive } \\
\text { animals }\end{array}$} & \multirow{2}{*}{$\begin{array}{l}\text { Mean PCV } \\
\text { of negative } \\
\text { animals }\end{array}$} \\
\hline & & Total positives & $\begin{array}{l}\text { T. Congolense } \\
(\%)\end{array}$ & $\begin{array}{l}\text { T. Vivax } \\
(\%)\end{array}$ & $\begin{array}{l}\text { Prevalence } \\
(\%)\end{array}$ & & \\
\hline 1-Kidongo & 61 & 32 & $\begin{array}{l}78.13 \\
(\mathrm{n}=25 / 32)\end{array}$ & $\begin{array}{l}21.88 \\
(\mathrm{n}=7 / 32) * *\end{array}$ & $\begin{array}{l}52.46 \\
(\mathrm{n}=32 / 61)\end{array}$ & $25.97 \pm 1.2$ & $33.62 \pm 1.2$ \\
\hline 2- Pengo & 35 & 13 & $\begin{array}{l}38.46 \\
(\mathrm{n}=5 / 13)\end{array}$ & $\begin{array}{l}61.54 \\
(\mathrm{n}=8 / 13)^{\mathrm{ns}}\end{array}$ & $\begin{array}{l}37.14 \\
(\mathrm{n}=13 / 35)\end{array}$ & $24.38 \pm 1.4$ & $29.5 \pm 1.1$ \\
\hline 3- Kizibe & 48 & 12 & $\begin{array}{l}41.67 \\
(\mathrm{n}=5 / 12)\end{array}$ & $\begin{array}{l}58.32 \\
(\mathrm{n}=7 / 12)^{\mathrm{ns}}\end{array}$ & $\begin{array}{l}25 \\
(\mathrm{n}=12 / 48)\end{array}$ & $24.17 \pm 1.6$ & $33 \pm 0.7$ \\
\hline 4- Mkongani & 54 & 9 & $\begin{array}{l}88.89 \\
(\mathrm{n}=8 / 9)\end{array}$ & $\begin{array}{l}11.11 \\
(\mathrm{n}=1 / 9) * *\end{array}$ & $\begin{array}{l}16.67 \\
(\mathrm{n}=9 / 54)\end{array}$ & $26.78 \pm 1.7$ & $29.76 \pm 0.6$ \\
\hline 5- Zunguluka & 51 & 13 & $\begin{array}{l}0 \\
(\mathrm{n}=0 / 13)\end{array}$ & $\begin{array}{l}100 \\
(\mathrm{n}=13 / 13) * *\end{array}$ & $\begin{array}{l}25.49 \\
(\mathrm{n}=13 / 51)\end{array}$ & $26.85 \pm 2$ & $33.16 \pm 0.7$ \\
\hline 6- Mangawani & 90 & 24 & $\begin{array}{l}41.67 \\
(\mathrm{n}=10 / 24)\end{array}$ & $\begin{array}{l}58.33 \\
(\mathrm{n}=14 / 24)^{\mathrm{ns}}\end{array}$ & $\begin{array}{l}26.67 \\
(\mathrm{n}=24 / 90)\end{array}$ & $31.29 \pm 1.4$ & $33.8 \pm 0.7$ \\
\hline 7- Mawiya & 56 & 26 & $\begin{array}{l}50 \\
(\mathrm{n}=13 / 26)\end{array}$ & $\begin{array}{l}50 \\
(\mathrm{n}=13 / 26)^{\mathrm{ns}}\end{array}$ & $\begin{array}{l}46.43 \\
(\mathrm{n}=26 / 56)\end{array}$ & $27.38 \pm 1.2$ & $30.57 \pm 0.8$ \\
\hline 8- Mkanda & 64 & 22 & $\begin{array}{l}72.73 \\
(\mathrm{n}=16 / 22)\end{array}$ & $\begin{array}{l}27.27 \\
(\mathrm{n}=6 / 22) * *\end{array}$ & $\begin{array}{l}34.38 \\
(\mathrm{n}=22 / 64)\end{array}$ & $27.68 \pm 1.1$ & $32.29 \pm 0.8$ \\
\hline 9- Katangini & 59 & 19 & $\begin{array}{l}89.47 \\
(\mathrm{n}=17 / 19)\end{array}$ & $\begin{array}{l}10.53 \\
(\mathrm{n}=2 / 19) * *\end{array}$ & $\begin{array}{l}32.2 \\
(\mathrm{n}=19 / 59)\end{array}$ & $27.89 \pm 0.8$ & $31.3 \pm 0.7$ \\
\hline 10- Msulwa & 66 & 28 & $\begin{array}{l}42.86 \\
(\mathrm{n}=12 / 28)\end{array}$ & $\begin{array}{l}57.14 \\
(\mathrm{n}=16 / 28)^{\mathrm{ns}}\end{array}$ & $\begin{array}{l}42.42 \\
(\mathrm{n}=28 / 66)\end{array}$ & $24.39 \pm 0.9$ & $31.29 \pm 0.9$ \\
\hline Total & 584 & 198 & $\begin{array}{l}56.06 \\
(\mathrm{n}=111 / 198)\end{array}$ & $\begin{array}{l}43.94 \\
(\mathrm{n}=87 / 198)^{*}\end{array}$ & $\begin{array}{l}33.9 \\
(n=198 / 584)\end{array}$ & $26.83 \pm 0.4$ & $32.01 \pm 0.3$ \\
\hline
\end{tabular}

*Significant $(\mathrm{p}<0.05) ; * *$; Highly significant $(\mathrm{p}<0.001)$; ns: Non significant $(\mathrm{p}>0.05)$

\subsection{Packed Cell Volume}

The mean PCV for all cattle in the study area was $30.26 \pm 0.2 \%$. The mean PCV of positive and negative animals ranged between $12-45 \%$ and $18-47 \%$, respectively (Fig. 2). The average PCV of infected animals $(26.83 \pm 0.4 \%)$ was significantly lower $(\mathrm{p}=$ $0.0001)$ than the average PCV of non-infected animals $(32.01 \pm 0.1 \%)$. But the average PCV of infected cattle did not differ significantly $(\mathrm{p}>0.05)$ between trypanosome species: $(26.35 \pm 5.6)$ and (27.45 46.4$)$ for $T$. congolense and $T$. vivax, respectively. Only $31.82 \%$ (63/198) of positive animals revealed PCV reading of less than $24 \%$ while $33.84 \%$ (67/198) of positive animals showed PCV readings of higher than $28 \%$ but no significant difference $(\mathrm{p}=0.67<0.05)$ was found between the two groups. The PCV value that is usually used as a cut-off for anaemia in cattle is $(\mathrm{PCV}<24 \%)$. Fourteen animals $(18.18 \%, 14 / 77)$ with PCV readings of below $24 \%$ were negative for trypanosomes, whereas $(68.18 \%, 135 / 198)$ with PCV reading above $24 \%$ were found positive for trypanosomes. The mean PCV decreased with increasing proportion of positive animals.

\subsection{Tsetse and Biting Flies Population}

Throughout the range of the tsetse survey area, the species found were Glossina pallidipes, G. austeni and G. brevipalpis but $G$. pallidipes was the most predominant species collected in all locations. There was a downward gradient in the apparent density of tsetse per site around the Shimba Hills National Reserve (Table 2). The apparent density varied widely between Locations. In the case of G. pallidipes, the number of tsetse flies caught per trap per day at a given Location varied between 8 (Pengo and Kidongo) and 76 (Zunguluka) with a mean of 30. G. pallidipes. In the case of $G$. austeni the catch per site varied between 0 and 6 with a mean of 0.8 flies per site per day; this species of tsetse fly was found only in five Locations of the areas surveyed. While, G. brevipalpis were found only in four Locations surveyed and the number of tsetse flies caught per trap per day varied between 0 and 4 with a mean of 0.4 (Table 2). Low population of Tabanidae were sampled in eight Locations and the number of flies caught per trap per day varied between 0 (Msulwa and Mangawani) and 1.3 (Zunguluka) with a mean of 0.5 (Table 3). Whereas Stomoxis were sampled in all sites and the number of flies caught per trap per day at a given Locations varied between 0.3 (Msulwa) and 4 (Pengo) with a mean of 1.7 (Table 3). 
Table 2. Tsetse flies species and apparent density (Flies/trap/day) in Kwale County

\begin{tabular}{|c|c|c|c|c|c|c|c|c|}
\hline \multirow[b]{2}{*}{ Locations } & \multicolumn{2}{|c|}{ G. pallidipes } & \multicolumn{2}{|c|}{ G. brevipalpis } & \multicolumn{2}{|c|}{ G. Austeni } & \multirow[b]{2}{*}{ Total } & \multirow[b]{2}{*}{ FTD } \\
\hline & Males & Females & Males & Females & Males & Females & & \\
\hline Kidongo & 37 & 11 & 0 & 0 & 2 & 0 & 50 & 8.30 \\
\hline Pengo & 38 & 8 & 0 & 0 & 0 & 0 & 46 & 7.70 \\
\hline Kizibe & 388 & 47 & 2 & 0 & 7 & 2 & 444 & 74.0 \\
\hline Mkongani & 75 & 10 & 0 & 0 & 0 & 0 & 115 & 19.2 \\
\hline Zunguluka & 424 & 31 & 2 & 0 & 0 & 1 & 458 & 76.3 \\
\hline Mangawani & 180 & 21 & 0 & 0 & 0 & 0 & 201 & 33.5 \\
\hline Mawiya & 62 & 10 & 0 & 0 & 0 & 1 & 73 & 12.2 \\
\hline Mkanda & 131 & 15 & 1 & 0 & 1 & 0 & 148 & 24.7 \\
\hline Katangini & 210 & 34 & 19 & 2 & 33 & 1 & 299 & 49.8 \\
\hline Msulwa & 69 & 7 & 0 & 0 & 0 & 0 & 78 & 13.0 \\
\hline
\end{tabular}

$\mathrm{n}$ : Number of fly; FTD: Fly/Trap/Day (apparent density of flies)

Table 3. Biting flies species and apparent density (Flies/trap/day) in Kwale County

\begin{tabular}{llccrr}
\hline Locations & Tabanidae & Stomoxidae & Other biting flies & Total & FTD \\
\hline Kidongo & 2 & 6 & 8 & 16 & 2.7 \\
Pengo & 2 & 22 & 48 & 72 & 103 \\
Kizibe & 4 & 20 & 79 & 34 & 17.0 \\
Mkongani & 2 & 10 & 22 & 86 & 5.7 \\
Zunguluka & 8 & 19 & 59 & 40 & 14.3 \\
Mangawani & 0 & 4 & 36 & 78 & 6.7 \\
Mawiya & 5 & 7 & 76 & 85 & 13.0 \\
Mkanda & 3 & 6 & 174 & 184 & 14.2 \\
Katangini & 4 & 6 & 5 & 7 & 30.7 \\
Msulwa & 0 & 2 & & 1.2 \\
\hline
\end{tabular}

$\mathrm{n}$ : Number of fly; FTD: Fly/Trap/Day (apparent density of flies)

\section{DISCUSSION}

The distribution of trypanosomosis, as suggested by the prevalence, showed a more or less similar situation around the Shimba Hills National Reserve. In all the areas, animals were infected by trypanosomes. The parasitological examination revealed a prevalence rate of $33.9 \%$ for bovine trypanosomosis with $T$. congolense $56.06 \%$ and Trypanosoma vivax $43.94 \%$ being the pathogenic trypanosomes identified. This study is in agreement with the findings of other researchers in various parts of Africa (Leak, 1999; McDermott et al., 2003), but our finding differed with previous data collected in the same Division by Ohaga et al. (2007) and also from Orma Boran cattle raised in Galana Ranch (Coastal Province in Kenya), over the past decade (19902000) indicated that there were significantly higher $T$. vivax infections in cattle as compared to $T$. congolense infections (Bett et al., 2004). Probably Localities where infections were due to $T$. vivax could be an indication of the presence of other potential haematophagus insect vectors other than tsetse flies. There is evidence that noncyclically transmitted $T$. vivax infection has been detected in other tsetse-free areas in Africa (Roeder et al., 1984). With a disease prevalence rate of $33.9 \%$, bovine trypanosomosis is seen to be a constraint to development in the region; this is supported by earlier research findings (Ohaga et al., 2007) who found a prevalence of $25 \%$ in the County and also (Murilla et al., 1998; Mugunieri and Murilla, 2003; Muraguri et al., 2005). However, earlier reports also indicate that the disease is only important to few farmers $(11.3 \%)$ in Kwale County (Machila et al., 2003). The pattern of parasitological prevalence in the different age groups, observed in Kwale County is not consistent with the findings of Desquesnes et al. (1999) who argued that older animals had more chances to be exposed to tsetse bites than younger ones. Most cattle of our study site graze and water close to Shimba Hills National Reserve where they come into contact with tsetse flies. The higher parasitological prevalence of bovine trypanosomosis observed in the County could be attributed to the higher trypanosome challenge around the National park which was subjected to annual re-invasion.

On the basic of the PCV readings, an assumption can be made on the infection status of animals with 
trypanosome. According to Stephen (1986), anaemia which is best measured by PCV, remains one of the indicators of trypanosomosis in cattle. In the present survey, $68.2 \%$ of positives animals showed PCV values of $>24 \%$ which is beyond the benchmark (Kelly, 1967), using parasitological technic. This finding can be explained by the fact that the microhaematocrit buffy coat technique of detecting trypanosomes in the blood is more sensitive, than that of direct smear examination for example (Paris et al., 1982). Earlier reports on the evaluation of the sensitivity of different diagnostic tests have shown to be, in decreasing order, that of microhaematocrit $>$ thick blood smear $>$ thin film $>$ wet film (Luckins, 1988). The low PCV values of trypanosomosis positive cattle is in agreement with previous findings, which noted that the disease reduced PCV levels in infected animals (Losos and Ikeda, 1972). Similarly, cattle with high prevalence of trypanosomosis have low haematocricrit levels (Mahama et al., 2004). However, other observations suggest that average herd PCV values are affected by other factor other than trypanosomosis (Connor, 1994). Poor nutrition is known to result in low PCV (Katunguka-Rwakishaga et al., 1995). Other causes include fasciolosis or haemonchosis (Zinsstag et al., 1998).

Result of tsetse and biting flies apparent densities confirm earlier findings by Ohaga et al. (2007) which observed that $G$. austeni, G. brevipalpis, G. pallidipes and biting flies were present in the survey area. Great variability in tsetse apparent densities observed by location could be explained by the fragmentation of tsetse habitat along riparian vegetation as described by Rocque et al. (2001). Although variations in humidity and temperature between dry and rainy season could have influenced tsetse fly population density from one location to another. It also should be noted that the vast and systematical use of trypanocidal drugs and the susceptibility of trypanosome populations to these drugs could have negatively confounded not only the conclusions drawn about the PCV values observed in the different cattle population but also about the prevalence of trypanosomosis in the County. Although resistance to trypanocidal drugs has been documented in Kwale County (Eisler et al., 2000) and others reports of drug resistance in other parts of West Africa (Clausen et al., 1992; Peregrine, 1994) suggest that this phenomenon should be taken into account when interpreting parasitological prevalence figures.

\section{CONCLUSION}

The study underscores the usefulness of crosssectional studies as a precursor to tsetse and trypanosomosis control interventions in the specific area. The results of the survey, besides identifying herds and villages where trypanosomosis constitutes a major problem, as far as animal health is concerned, also provided information on the prevalence of trypanosome species and strains as well as their vectors in the Kwale District. It is recommended that the District fulfill all the laid down criteria's to be chosen for a large scale field trial of tsetse repellent technology.

\section{ACKNOWLEDGEMENT}

This survey was undertaken by Animal Health Division, International Centre for Insect Physiology and Ecology (ICIPE). Farmers and all staff assisting with the survey: Phillip Kolei, Satia and Charles are kindly acknowledged. The work was funded by the European Union (Grant Number: DCI-FOOD/2009/200240).

\section{REFERENCES}

Bett, B., C. Orenge, P. Irungu and L.K. Munga, 2004. Epidemiological factors that influence time-totreatment of trypanosomosis in orma boran cattle raised at Galana ranch, Kenya. Vet. Parasitol., 120: 43-53. DOI: 10.1016/j.vetpar.2003.12.011

Cannon, R.M. and R.T. Roe, 1982. Livestock Diseases Surveys: A Field Manual for Veterinarians. 1st Edn., Australian Government Publishing Services, Canberra, ISBN-10: 0644021012, pp: 35.

Clausen, PH, I. Sidibe, I. Kabore and B. Bauer, 1992. Development of multiple drug resistance of Trypanosoma congolense in Zebu cattle under high natural tsetse fly challenge in the pastoral zone of Samorogouan, Burkina Faso. Acta Tropica, 51: 229236. DOI: 10.1016/0001-706X(92)90041-U

Connor, R.J. and P.V.D. Bossche, 2004. African animal trypanosomoses. In: Infectious Diseases of Livestock, Coetzer, J.A.W. and R.C. Tustin (Eds.), Oxford University Press southern Africa, Cape Town, ISBN-10: 0195761715, pp: 251-296.

Connor, R.J., 1994. African Animal Trypanosomosis. In: Infectious Diseases of Livestock with Special Reference to Southern Africa, Coetzer, J.A.W., G.R. Thomson and R.C. Tustin (Eds.), Oxford University Press, Cape Town, ISBN-10: 0195709195, pp: 166-203.

Corp, S., 2006. Stata Statistical Software: Release 9.2. Stata CORPoration, Texas.

D'Ieteren, G.D.M., E. Authie, N. Wissocq and M. Murray, 1998. Trypanotolerance, an option for sustainable livestock production in areas at risk from trypanosomosis. Rev. Sci. Tech. Off. Int. Epiz., 17: 154-175. PMID: 9638808 
Desquesnes, M., J.F. Michel, P. Solano, L. Millogo and Z. Bengaly et al., 1999. Enquête parasitologique et sérologique (Elisa-indirect) sur les trypanosomoses des bovins dans la zone de Sideradougou, Burkina Faso. Rev. Elev. Med. Vet. Pays Trop., 52: 223-232.

Eisler, M.C, J.J. McDermott, R.E. Mdachi, G. Murilla and L. Sinyangwe et al., 2000. Rapid method for the assessment of trypanocidal drug resistance in the field. Proceedings of the 9th Symposium of the International Society for Veterinary Epidemiology and Economic, (ISVEE' 00), Breckenridge, Colorado, USA., pp: 353-353.

Geerts, S., P.H. Holmes, M.C. Eisler and O. Diall, 2001. African bovine trypanosomiasis: The problem of drug resistance. Trends Parasitol., 17: 25-28. DOI: 10.1016/S1471-4922(00)01827-4

Holmes, P.H., 1997. New approaches to the integrated control of trypanosomosis. Vet. Parasitol., 71: 121135. PMID: 9261974

Jaetzold, R. and H. Schimdt, 1983. Farm management handbook of Kenya. Ministry of Agriculture, Farm Management Section, Nairobi.

Jordan, A.M., 1986. Trypanosomiasis Control and African Rural Development. 1st Edn., Longman, London, ISBN-10-10: 0582463564 pp: 357.

Katunguka-Rwakishaga, E., J.J. Parkins, G. Fishwick, M. Murray and P.H. Holmes, 1995. The influence of energy intake on the pathophysiology of Trypanosoma congolense infection in Scottish Blackface sheep. Vet. Parasitol., 59: 207-218. DOI: 10.1016/0304-4017(94)00748-2

Kelly, W.R., 1967. Veterinary Clinical Diagnosis. 1st Edn., Williams and Wilkins Co., Baltimore, pp: 294.

Leak, S.G.A., 1999. Tsetse Biology and Ecology: Their Role in the Epidemiology and Control of Trypanosomosis. 1st Edn., ILRI (aka ILCA and ILRAD), Wallingford, ISBN-10: 0851993001, pp: 568.

Losos, G.L. and I. Ikeda, 1972. Review of Pathology of Diseases in Domestic and Laboratory Animals Caused by Trypanosoma congolense, T. vivax, $T$. brucei, T. rhodesiense and T. gambiense. Vet. Pathol., 9: 1-79. DOI: 10.1177/030098587200901s01

Luckins, A.G., 1988. Trypanosoma evansi in Asia. Parasitol., Today, 4: 137-142. DOI: 10.1016/01694758(88)90188-3

Machila, N., S.W. Wanyangu, J.J. McDermott, S.C. Welburn and I. Maudlin et al., 2003. Cattle owners' perceptions of African bovine trypanosomiasis and its control in Busia and Kwale Districts of Kenya. Acta Trop., 86: 25-34. DOI: 10.1016/S0001706X(02)00288-7
Mahama, C.I., M.I. Desquesnes, R. Losson, R. Dedeken and S. Geerts, 2004. A cross-sectional epidemiological survey of bovine trypanosomosis and its vectors in the Savelugu and west Mamprusi districts of northern Ghana. Vet. Parasitol., 122: 113. DOI: 10.1016/j.vetpar.2004.03.009

McDermott, J., T. Woitag, I. Sidibe, B. Bauer and B. Diarra et al., 2003. Field studies of drug-resistant cattle trypanosomes in Kenedougou Province, Burkina Faso. Acta Trop., 86: 93-103. DOI: 10.1016/S0001-706X(03)00019-6

Mugunieri, G.L. and G.A. Murilla, 2003. Resistance to trypanocidal drugs--suggestions from field survey on drug use in Kwale district, Kenya. Onderstepoort J. Vet. Res., 70: 29-36. PMID: 12825678

Muraguri, G.R., A. McLeod, J.J. McDermott and N. Taylor, 2005. The incidence of calf morbidity and mortality due to vector-borne infections in smallholder dairy farms in Kwale District, Kenya. Vet. Parasitolol., 130: 305-315. DOI: 10.1016/j.vetpar.2004.11.026

Murilla, G.A., R.E. Mdachi, G.O. Okech and J.M. Ndungu, 1998. Novel approaches to the epidemiology of resistance to drugs used in the control of bovine trypanosomiasis in East Africa.

Murray, M., P.K. Murray and W.I. McIntyre, 1977. An improved parasitological technique for the diagnosis of African trypanosomiasis. Trans. R. Soc. Trop. Med. Hyg., 71: 325-326. PMID: 563634

Njenga, S.M., C.S. Mwandawiro, E. Muniu, M.T. Mwanje and F.T. Haji et al., 2011. Adult population as potential reservoir of NTD infections in rural villages of Kwale district, Coastal Kenya: implications for preventive chemotherapy interventions policy. Parasites Vectors, 4: 175-175. DOI: $10.1186 / 1756-3305-4-175$

Ohaga, S.O, E.D. Kokwaro, I.O. Ndiege, A. Hassanali and R.K. Saini, 2007. Livestock farmers' perception and epidemiology of bovine trypanosomosis in Kwale District, Kenya. Prev. Vet. Med., 80: 24-33. DOI: 10.1016/j.prevetmed.2007.01.007

Paris, J., M. Murray and F. McOdimba, 1982. A comparative evaluation of the parasitological techniques currently available for the diagnosis of African trypanosomiasis in cattle. Acta Trop., 39: 307-316. PMID: 6131590

PATTEC, 2000. Pan African Tsetse and Trypanosomiasis Eradication Campaign. African Union Commission. 
Peregrine, A.S., 1994. Chemotherapy and delivery systems: Haemoparasites. Vet. Parasitol., 54: 223248. DOI: 10.1016/0304-4017(94)90092-2

Rocque, S.D.L., J.F. Michel, D. Cuisance, G. Dewispeleare and P. Solano et al., 2001. Le Risque Trypanosomien: Du Satellite au Microsatellite: Une Approche Globale pour une Decision Locale. 1st Edn., Editions Quae, Montpellier, ISBN-10: 2876144697, pp: 151.

Roeder, P.L., J.M. Scott and R.G. Pegram, 1984. Acute Trypanosoma vivax infection of Ethiopian cattle in the apparent absence of tsetse. Trop. Anim. Health Prod., 16: 141-147. PMID: 6485103

Stephen, L.E., 1986. Trypanosomiasis: A Veterinary Perspective. 1st Edn., Pergamon Press, Oxford, ISBN-10: 0080320171, pp: 551.
Swallow, B.M., 1999. Impacts of trypanosomiasis on African agriculture. FAO.

Thorpe, W., F. Chabari, S. Maloo, R. Muinga and A. Mukhebi et al., 1993. Smallholder dairy cattle production in coastal Kenya: Resource base assessment and constraint identification. Proceedings of the Meeting Heid at Animal Production in Developing Countries, (HAPDC' 93), BSAP, Penicuik, Scotland, UK., pp: 167-168.

Zinsstag, J.P. Ankers, M. Ndao, H. Bonfoh and K. Pfister, 1998. Multiparasitism, production and economics in domestic animals in sub-saharan West Africa. Parasit. Today, 14: 46-49. DOI: 10.1016/S0169-4758(97)01183-6 